This page intentionally left blank 


\section{Back to the}

Future in the

Caves of Kaua $\dot{i}$

A Scientist's

Adventures in the Dark

David A. Burney

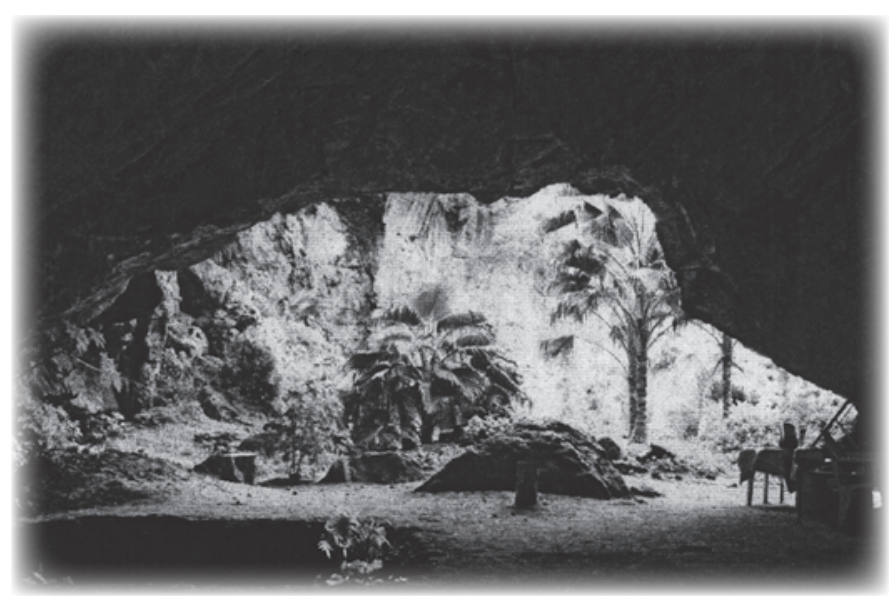

Yale

UNIVERSITY PRESS

New Haven \& London 
Copyright (C) 2010 by David Burney.

All rights reserved.

This book may not be reproduced, in whole or in part, including illustrations, in any form (beyond that copying permitted by Sections 107 and 108 of the U.S. Copyright Law and except by reviewers for the public press), without written permission from the publishers.

Set in Monotype Bulmer by Duke \& Company, Devon, Pennsylvania.

Printed in the United States of America by Sheridan Books, Ann Arbor, Michigan.

\section{Library of Congress Cataloging-in-Publication Data}

Burney, David A., 1950-

Back to the future in the caves of Kaua' $\mathrm{i}$ : a scientist's adventures in the dark /

David A. Burney.

p. $\mathrm{cm}$.

Includes bibliographical references and index.

ISBN 978-0-300-15094-o (alk. paper)

1. Kauai (Hawaii)-Antiquities. 2. Excavations (Archaeology)-Hawaii-Kauai.

3. Caves-Hawaii-Kauai. 4. Paleoecology-Hawaii-Kauai. 5. Prehistoric peoplesHawaii-Kauai. 6. Human ecology-Hawaii-Kauai-History. 7. Nature-Effect of human beings on-Hawaii-Kauai-History. 8. Time-Philosophy. 9. Kauai (Hawaii)-Environmental conditions. 10. Burney, David A., 1950--Travel-HawaiiKauai. I. Title.

DU628.K3B87 2010

$$
996.9^{\prime} 4102-\mathrm{dc} 22
$$

A catalogue record for this book is available from the British Library.

This paper meets the requirements of ANSI/NISO Z39.48-1992 (Permanence of Paper).

$$
\begin{array}{llllllllll}
10 & 9 & 8 & 7 & 6 & 5 & 4 & 3 & 2 & 1
\end{array}
$$


In memory of Eloise Nelson Pigott (1925-2004) 
This page intentionally left blank 


\section{What is it?}

petrified Pleistocene sand pile

the plumbing of a sacred spring

subterranean tide-pool

fresh dark water in a coastal desert

big pickling jar full of old landscapes

millennium of garbage dumps

poachers' hideout

warriors' garrison

battlefield

place of divination

Chinese opium den

hippie commune

movie set

witches' gathering place

victim of tempest and tsunami

place of restoration

Poor Man's Time Machine

Makauwahi Cave. 
This page intentionally left blank 